\title{
Pink-eyed Dilution, a Coat Color Mutation in the Japanese Field Vole (Microtus montebelli)
}

\author{
Katsuhiro FUKUTA, Kenkichi IMAMURA, and Nobuo GOTO* \\ National Institute of Animal Health, Kannondai, Tsukuba-shi, Ibaraki 305, and ${ }^{*}$ Faculty of \\ Agriculture, Kobe University, Rokko, Nada-ku, Kobe-shi, Hyogo 657, Japan
}

(Received 30 November 1990/Accepted 22 January 1991)

\begin{abstract}
Inheritance of dilute coat color with pink eye in the Japanese field vole (Microtus montebelli) was investigated by mating of the dilute mutant with a normal agouti vole and a white vole. As the results, it was cleared that an autosomal recessive gene $p$ is responsible for the pink-eyed dilution in $M$. montebelli. - KEY WORDS : coat color, microtus, pink-eyed dilution
\end{abstract}

The vole (genus Microtus) is one of the small herbivorous rodents having multichambered stomach, so it has possibility to be a useful experimental animal alternating to herbivorous domestic animals. From the viewpoint to develop the vole as an experimental animal, we have reared the Japanese field vole (Microtus montebelli) in our laboratory $[6,7]$. Original coat color of the wild vole is normal agouti with dark grey or brown on dorsum and ash-colored on abdomen (Fig. 1).

In general, coat color mutations of a wild rodent have been detected frequently in course of its breeding in the laboratory. Regarding Microtus montebelli, Saito [16] detected a white vole (varying from white to cream in coat color), and succeeded in its breeding (Fig. 2). He estimated that the mutant of this coat color was controlled by an autosomal recessive gene. Pink-eyed dilution (Fig. 3), another coat color mutation of $M$. montebelli, was detected in the breeding colony at the Forestry and Forest Products Research Institute. Both mutants of white and dilute coat colors were introduced into our laboratory and proliferated. In the present investigation, we describe the inheritance of pink-eye dilution in $M$. montebelli.

Mating experiments were carried out using three kinds of Japanese field voles of different coat color, i. e., normal agouti, white, and pink-eyed dilution (or shortened as 'dilute' ), all of which were maintained at the National Institute of Animal Health. Number of offspring were 47 heads (male 23, female 24) in the mating experiment between agouti and dilute, and 85 heads (male 44, female 41) between white and dilute. Coat color was judged by the naked eye.

Throughout the experiments, all the animals were raised in a room conditioned to a temperature of $23-24^{\circ} \mathrm{C}$ and a humidity of 50 $60 \%$. The voles were fed on commercial pellets for mice and lucerne cubed hay after their weaning. They took food and water ad libitum.

According to the morphological observation of the vole under the laboratory husbandry [12], hair appears to grow about 4 days of age, though not seen at birth. Eyelid opening averages 7.9 days of age. Since the appearance time of these features in the dilute vole is the same as that in the normal agouti, the dilution with pink eye can be identified at 8 days of age. A young dilute vole can be easily discriminated from others by its agouti silver coat color (Fig. 4).

Table 1 shows the number of offspring classified by coat color in $\mathrm{F}_{1}$ hybrid (agouti $\times$ dilute) and in $\mathrm{BCF}_{1}$ (backcross of $\mathrm{F}_{1}$ to dilute). The mating between normal agouti and dilute voles produced $F_{1}$ young of normal agouti. When a few $F_{1}$ animals, which might be heterozygous for dilute on marker gene, were back- 
Table 1. Number of voles classified by coat color in (agouti $\times$ pink-eyed dilution) $-\mathrm{F}_{1}$ and backcross $\mathrm{BCF}_{1}$

\begin{tabular}{cccccc}
\hline Dam $\times$ Sire & $\begin{array}{c}\text { No. of } \\
\text { litter }\end{array}$ & Sex & \multicolumn{2}{c}{ Coat color in offsprings } & $X^{2}$ - test $^{* *}$ \\
\hline \multirow{2}{*}{ agouti $\times$ dilute } & 4 & Male & 10 & 0 & \\
& & Female & 11 & 0 & \\
\cline { 3 - 6 } & & Total & 21 & 0 & \\
\hline \multirow{2}{*}{$\mathrm{F}_{1} \times$ dilute } & 5 & Male & 5 & 8 & $0.25<\mathrm{P}<0.50$ \\
& & Female & 6 & 7 & $0.50<\mathrm{P}<0.75$ \\
\cline { 3 - 6 } & & Total & 11 & 15 & $0.50<\mathrm{P}<0.76$ \\
\hline
\end{tabular}

* pihk-eyed dilution $\quad{ }^{* *}$ Null hypothesis ; an autosomal recessive gine $p$ is responsible for pink-eyed dilution. The same as in the following tables.

Table 2. Number of voles classified by coat color in (white $\times$ dilute) $-F_{1}$ and backross $B C F_{1}$

\begin{tabular}{cccccc}
\hline Dam $\times$ Sire & $\begin{array}{c}\text { No. of } \\
\text { litter }\end{array}$ & Sex & \multicolumn{2}{c}{ Coat color in offsprings } & $X^{2}$-test \\
\hline \multirow{2}{*}{ white $\times$ dilute } & 3 & Male & 4 & 0 & \\
\cline { 3 - 5 } & & Female & 6 & 0 & \\
\cline { 3 - 6 } & & Total & 10 & 0 & \\
\hline \multirow{2}{*}{$\mathrm{F}_{1} \times$ dilute } & 6 & Male & 6 & 10 & $0.10<\mathrm{P}<0.25$ \\
& & Female & 7 & 8 & $0.50<\mathrm{P}<0.75$ \\
\cline { 3 - 6 } & & Total & 13 & 18 & $0.25<\mathrm{P}<0.50$ \\
\hline
\end{tabular}

Table 3. Number of voles classified by coat color in (white $\times$ dilute $)-F_{2}$

\begin{tabular}{ccccccccc}
\hline Dam & $\times$ & Sire & $\begin{array}{c}\text { No. of } \\
\text { litter }\end{array}$ & Sex & \multicolumn{2}{c}{ Coat color in offsprings } & & $X^{2}$-test \\
\hline \multirow{2}{*}{$F_{1}$} & $\times$ & $F_{1}$ & \multirow{2}{*}{10} & Male & 17 & 5 & 2 & $0.25<\mathrm{P}<0.50$ \\
& & & Female & 12 & 3 & 5 & $0.25<\mathrm{P}<0.50$ \\
\cline { 4 - 7 } & & Total & 29 & 8 & 7 & $0.25<\mathrm{P}<0.50$ \\
\hline
\end{tabular}

crossed to dilute mutants, $\mathrm{BCF}_{1}$ were 11 normal agouti and 15 dilutes. The result deviates slightly from expected 1 : 1 backcross ratio $\left(X^{2}=\right.$ $0.346,0.50<\mathrm{p}<0.75)$.

Table 2 shows the result of the mating between white and dilute voles. In $M$. montebelli white in coat color is controlled by an autosomal recessive gene. We express the gene by a symbol $+^{{ }^{c r m}}$ tentatively, depending on its indeed coat color rather cream than white, and its allelic non-white gene (exhibiting agouti) by a symbol $+^{\text {crm }}$. As seen in the Table 2, all $\mathrm{F}_{1}$ animals were agouti in color. In $\mathrm{BCF}_{1}\left(\mathrm{~F}_{1} \times\right.$ dilute), agouti (13 heads) and dilute (18 heads) were seen at the ratio of nearly $1: 1\left(X^{2}=\right.$ $0.516,0.25<\mathrm{p}<0.50)$. The mating between $\mathrm{F}_{1}$ hybrids produced $44 \mathrm{~F}_{2}$ voles; consisting of 29 normal agouti, 8 white, and 7 dilute (Table 3 ). This is statistically within a deviation from the ratio of 9 agouti : 3 white : 3 dilute : 1 white with pink eye that would be expected if pink-eyed dilution (gene symbolized as $p$ ) is a 
Table 4. Color aberrations in Microtus species

\begin{tabular}{|c|c|c|c|}
\hline Color & Species & Inheritance & Researchers \\
\hline Albino & $\begin{array}{l}\text { M. arvalis } \\
\text { M. pennsylvanicus } \\
\text { M. pennsylvanicus } \\
\text { M. montanus } \\
\text { M. montebelli }\end{array}$ & $\begin{array}{l}\text { recessive } \\
\text { recessive? }\end{array}$ & $\begin{array}{l}\text { Frank und Zimmermann } \\
\text { Barrett }^{11} \\
{\text { Sillman \& } \text { Wellwood }^{181}} \\
\text { Jannett }^{9)} \\
\text { Watanabe }^{21)}\end{array}$ \\
\hline Black & $\begin{array}{l}\text { M. arvalis } \\
M . \text { ochrogaster }\end{array}$ & $\begin{array}{l}\text { recessive } \\
\text { recessive? }\end{array}$ & $\begin{array}{l}\text { Frank und Zimmermann } \\
\text { Semeonoff }^{\text {(7) }}\end{array}$ \\
\hline Melanism & M. pennsylvanicus & & Blossom $^{3 \prime}$ \\
\hline Light brown & $\begin{array}{l}\text { M. pinetorum } \\
M . \text { pennsylvanicus }\end{array}$ & & $\begin{array}{l}\text { Owen \& Shackelford }{ }^{13)} \\
\text { Owen \& Shackelford }^{13)}\end{array}$ \\
\hline Yellow & $\begin{array}{l}M . \text { pennsylvanicus } \\
M . \text { pinetorum }\end{array}$ & & $\begin{array}{l}\text { Owen \& Shackelford }{ }^{13)} \\
\text { Owen \& Shackelford }^{13)}\end{array}$ \\
\hline Creamy & M. pennsylvanicus & recessive & Clark $^{4)}$ \\
\hline Silver & M. arvalis & recessive & Frank und Zimmermann ${ }^{5)}$ \\
\hline Ivory & M. arvalis & recessive & Frank und Zimmermann ${ }^{5)}$ \\
\hline Chinchilla & M. arvalis & recessive & Frank und Zimmermann ${ }^{5)}$ \\
\hline White & M. montebelli & recessive & Saito $^{16)}$ \\
\hline Smoky & $\begin{array}{l}\text { M. arvalis } \\
\text { M. ochrogaster }\end{array}$ & & $\begin{array}{l}\text { Frank und Zimmermann } \\
\text { Pinter \& Negus } \\
{ }^{5)}\end{array}$ \\
\hline Dilute & M. ochrogaster & recessive & Semeonoff ${ }^{17)}$ \\
\hline Pale cinnamon & M. pennsylvanicus & recessive? & Kutz and Smith ${ }^{111}$ \\
\hline Pink-eyed dilution & $\begin{array}{l}\text { M. arvalis } \\
\text { M. pennsylvanicus } \\
M . \text { schermans }\end{array}$ & $\begin{array}{l}\text { recessive? } \\
\text { recessive }\end{array}$ & $\begin{array}{l}\text { Frank und Zimmermann } \\
\text { Owen \& Shackelford }{ }^{13)} \\
\text { Owen \& Shackelford }{ }^{13)}\end{array}$ \\
\hline Extreme dilute & M. pennsylvanicus & dominant & Barrett $^{2)}$ \\
\hline Piebald & M. pennsylvanicus & & Clark $^{4)}$ \\
\hline Dominant spotting & $\begin{array}{l}\text { M. montanus } \\
\text { M. arvalis }\end{array}$ & $\begin{array}{l}\text { dominant } \\
\text { dominant }\end{array}$ & $\begin{array}{l}\text { Pinter }{ }^{15)} \\
\text { Sugawara et al. }{ }^{20)}\end{array}$ \\
\hline White spotting & $\begin{array}{l}\text { M. ochrogaster } \\
\text { M. pennsylvanicus }\end{array}$ & recessive & $\begin{array}{l}\text { Hartke et al. } \\
\text { Owen \& Shackelford } \\
\end{array}$ \\
\hline Recessive spotting & M. arvalis & recessive & Frank und Zimmermann ${ }^{5)}$ \\
\hline
\end{tabular}

simple Mendelian unit character $\left(X^{2}=3.677\right.$, $0.25<\mathrm{p}<0.50$ )

Based on the literatures, color aberrations in genus Microtus, are summarized as in Table 4. As for $M$. montebelli, two variants of coat color, albino $[10,21]$ and white $[16]$, were reported. Only white voles are maintained in the laboratory [16].

Coat color inheritance in wild rodents is generally referred to that in laboratory mice. In mice, color of pelage depends upon $B-b$ and $A-a$ locus. The former controls the synthesis of melanin pigment, while the latter controls the pigment distribution in cach hair. Combination of $A-a$ and $B-b$ reveals four basic coat colors, i. e., agouti, black, cinnamon and chocolate. In addition, there is $C_{-c}$ locus which is responsible for the presence of the pigment. Mice having a genotype $c / c$ result in albino, regardless of genotype of loci $A-a$ and $B-b$. And autosomal recessive gene is responsible for the dilution with pink eye [19].

Also in genus Microtus, four basic coat colors were observed as well as in laboratory mice (Table 4 ). The mode of coat color inheritance in Microtus seemed to be similar to that in the mice. However, we cannot confirm whether the inheritance of coat color in $M$. montebelli is the same as laboratory mice, because no coat color variants of them have not been bred in the laboratory except for normal agouti and white.

In the present study, we hypothesized crm as a symbol of white gene and $+^{\mathrm{crm}}$ as its allelic 
non-white gene in $M$. montebelli, and mated dilute voles with agouti, homozygous for $+^{c r m}$, and with white, homozygous for $\mathrm{crm}$. As the results, it was cleared that dilution with pink eye in $M$. montebelli depends upon an autosomal recessive gene located in the different locus from $\mathrm{crm}$ for its expression. We named the gene as pink-eyed dilution expressed by a symbol $p$ and its allelic gene by $+^{p}$. So the genotypes of three kinds of the voles are represented by $+^{c r m} /+^{c r m} ;+^{p /}++^{p}$ for agouti, $\mathrm{crm} /$ crm $;+^{p} /+^{p}$ for white, and $+^{c r m} /+^{c r m} ; p / p$ for dilute.

In $\mathrm{F}_{2}$ (descendent of white $\times$ diute), white vole with pink eye $(\mathrm{crm} / \mathrm{crm} ; \mathrm{p} / \mathrm{p})$ was not found, although it would be expected at the ratio of $1 / 16$ theoretically. Recently we have detected 4 white voles with pink eye in the offspring between dilutes $\left(+{ }^{c r m} / c r m ; p / p \times+c r m\right.$ $/ \mathrm{crm} ; p / p)$. However, neither agouti with pink eye nor dilute with normal dark eye were found in our colony. These facts support that the gene $p$ is responsible for the pink-eyed dilution in M. montebelli.

\section{References}

[1] Barrett, G. W. (1975). Ohio J. Sci, 75, 102.
[2] Barrett, G. W. (1976). J. Hered, 67, 109-110.

[3] Blossom, P. M. (1942). J. Mammal, 23, 214.

[4] Clark, F. H. (1938). J. Hered, 29, 265-266.

[5] Frank, von F. und Zimmermann, K. (1957). Z Saugetierk, 22, 87-99.

[6] Goto, N., Hashizume, R., and Sai, I. (1977). J. Mammal Soc. Jpn, 7, 75-85.

[7] Goto, N. and Hashizume, R. (1978). J. Mammal Soc. Jpn, 7, 181-188.

[8] Hartke, G. T., Leipold, H. W., Huston, K., Cook, J. E., and Saperstain, G. (1974). J Hered, 65, 301-301.

[9] Jannett, F. J. (1981). J. Hered, 72, 144-146.

[10] Komatsu, T. (1955). Saishuu to Shiiku 17, 43-46.

[11] Kutz, H. J. and Smith, R. H. (1945). J. Mammal, 26, 307-308.

[12] Obara, I. (1975). J. Mammal Soc. Jpn, 6, 107-114.

[13] Owen, R. D. and Shackelford, R. M. (1942). J. Mammal, 23, 306-314.

[14] Pinter, A. J. and Negus, N. C. (1971). J. Mammal, 52, 196-199.

[15] Pinter, A. J. (1979). J. Hered, 70, 213-214.

[16] Saito, T. (1982). Exp. Anim, 31, 287-289.

[17] Semeonoff, R. (1972). J. Hered, 63, 48-52.

[18] Sillman, E. I. and Wellwood, A. A. (1956). J. Mammal, 37, 298.

[19] Sivers, W. K. (1979). The Coat Colors of Mice, Splinger-Verlag, New York-Heidelberg-Berlin.

[20] Sugawara, M., Kiritani, R., and Oki, Y. (1987). Exp. Anim, 36, 1-9.

[21] Watanabe, K. (1962). Tech Bull Miyagi Pref. Agr. Exp. St., 31, 1-104.

\title{
ハタネズミ(Microtus montebelli)における pink-eyed dilution の遺伝
}

\author{
福田勝洋·今村憲吉·後藤信男*
}

農林水産省家畜衛生試験場

*神戸大学農学部家畜育種学教室

本邦産ハタネズミ(Microtus montebelli)に出現し た紅眼を伴ら淡色毛 (pink-eyed dilution) の遺伝様式 を，野生色および白色ハタネズミと交配することによっ
て調べた。その結果, この形質は常染色体劣性遺伝子に よって支配されていることが明らかになった。この遺伝 子を pink-eyed dilution, 遺伝子記号を $p$ と命名した。

\section{Explanation of Figures}

Fig. 1. Normal agouti vole

Fig. 2. White vole

Fig. 3. Dilute vole with pink eye
Fig. 4. Young voles of pink-eyed dilution. One vole shows agouti silver pelage which appears only in its infancy. 


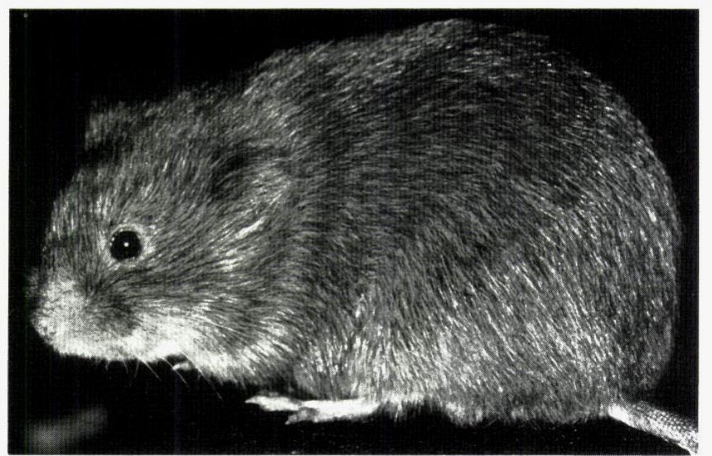

Fig. 1.

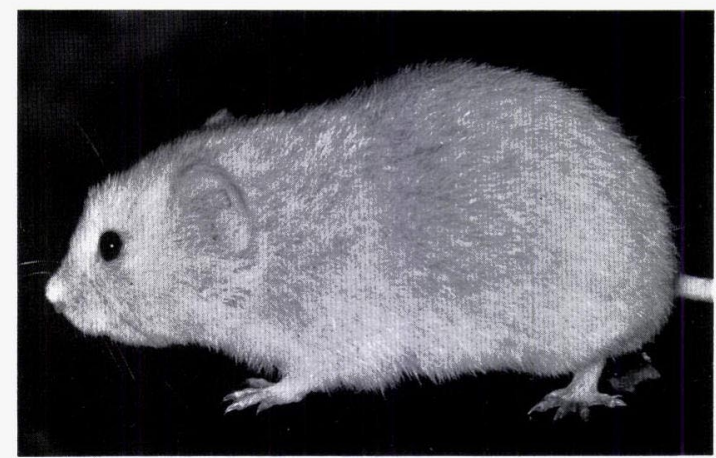

Fig. 2.

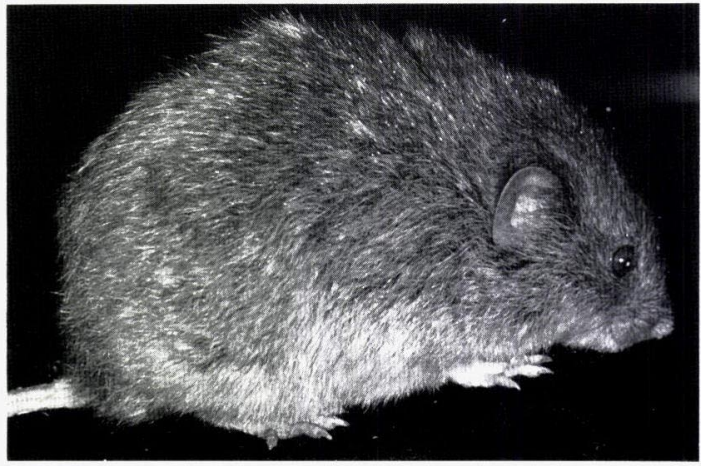

Fig. 3.

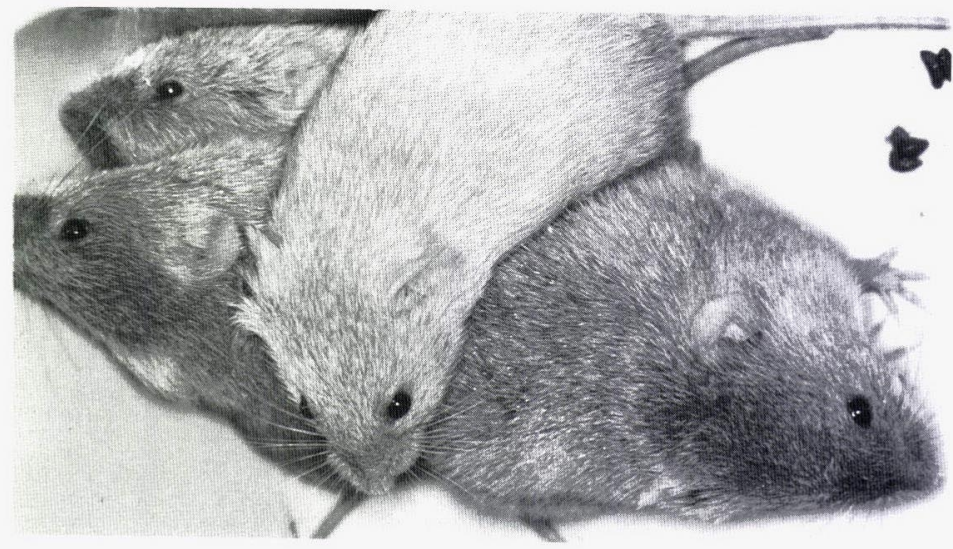

Fig. 4. 